\title{
The Effect of Addition Electrical Supercharger on Diesel Dual Fuel Engine with Variation of Air Mass Flow Rate to The Engine Performance and Emissions
}

\author{
Jamaludin $^{1}$, Dori Yuvenda ${ }^{1}$, and Bambang Sudarmanta ${ }^{1}$
}

\begin{abstract}
Diesel Dual fuel system is a diesel operated by using dual fuel CNG and diesel fuel as a pilot fuel. The problem that often occurs in dual fuel system is the reduced ratio of air and fuel. This causes the thermal efficiency to be lower. So in this study mounted electric supercharger as an air supply for performance and efficiency, and emissions from diesel engines better. This research uses diesel engine type Diamond Di 800 with dual fuel indirect injection model system. The method used is to vary the air mass flow rate $(\dot{m})$ through intake manifold to the combustion chamber $0.0063 \mathrm{~kg} / \mathrm{s}, 0.0072 \mathrm{~kg} / \mathrm{s}, 0.0077 \mathrm{~kg} / \mathrm{s}$, $0.0087 \mathrm{~kg} / \mathrm{s}$, and $0.0095 \mathrm{~kg} / \mathrm{s}$ by adjusting the voltage on electric supercharger $8 \mathrm{~V}, 9 \mathrm{~V}, 10 \mathrm{~V}, 11 \mathrm{~V}$, and $12 \mathrm{~V}$. Measurements are made to: the current and the voltage of each load, the consumption time of $25 \mathrm{ml}$ diesel fuel, and the exhaust emissions (CO, HC, and PM). The best result was found that the addition of air mass flow rate (i) to dual fuel system had no significant effect on the engine's effective power, torque, Bmep when compared with single fuel. The addition of air mass flow rate $(\dot{m}) 0.0087 \mathrm{~kg} / \mathrm{s}$ can substitution the diesel fuel by $56.45 \%$, thermal efficiency increased by $33.57 \%$ but under single fuel condition, and increase the average AFR by $64.31 \%$. The average $\mathrm{CO}$ and $\mathrm{HC}$ emissions decreased by $15.18 \%$ and $62.35 \%$ even though they were under single fuel condition, while the PM emissions increase with increasing loads but compared to single fuel decreased by $75 \%$.
\end{abstract}

Keywords- Electric Supercharger, Diesel Engine Diamond Type DI 800, Engine Performance, Mass Flow Rate.

\section{INTRODUCTION}

Diesel Dual Fuel (DDF) is a standard diesel engine that added another fuel to the intake manifold and fuel ignition is done by a diesel fuel spray called a pilot fuel. For internal combustion engines, especially diesel engines, the pilot fuel used is diesel fuel. Where the working principle of diesel engine is compressed ignition engine (ICE) or ignition with pressure that requires fuel that has cetane number content, so it needs fuel lighter.

The stage of combustion process in a dual fuel diesel engine system is a sequential mode that includes the combustion of pilots diesel and the burning of gas fuel.

\footnotetext{
${ }^{1}$ Jamaludin, Dori Yuvenda, and Bambang Sudarmanta are with Departement of Mechanical Engineering, Institut Teknologi Sepuluh Nopember, Surabaya, 60111, Indonesia. E-mail: jamaludin16@mhs.me.its.ac.id; _ doriyuvenda@ft.unp.ac.id; sudarmanta@me.its.ac.id.
}

Konigsson [1], describes the combustion process in a diesel dual fuel engine occurs in sequential, the first stage pilot diesel burning, the second stage of combustion methane gas, the third stage of propagation fire in methane and air mixture, the fourth bulk ignition stage the end gas mixture.

In general, dual fuel systems experience problems in the reduced ratio of air and fuel. The amount of combustion air is reduced due to the introduction of alternative fuels in the intake, thus causing the AFR to be lower. A low AFR causes a rich mixture of combustion, resulting in lower thermal efficiency because the fuel does not burn completely. In Compressed Ignition Engine (CIE), the ideal air and fuel ratio is $18 \leq \mathrm{AFR} \leq 70$ [2].

Yuvenda and Sudarmanta [3], conducted a research using a Diamond type Di 800 engine with a dual fuel indirect injection system model by varying the spring and gas pressure constants out on stage two. The best results were obtained at the spring constant of $27.55 \mathrm{~N} / \mathrm{m}$ and 2.5 bar pressure increased the flow rate of $7.42 \%$, substituted CNG replaced diesel fuel by $60.2 \%$ with an average increase of SFC dual fuel by $27,5 \% \mathrm{~kg} / \mathrm{Hp} . \mathrm{h}$ and lowered the average SFC diesel by $59.4 \%$, decreased average thermal efficiency by $21.2 \%$ and the average AFR decrease by $37.5 \%$. Arif and Sudarmanta [4], conducted an experiment by injection CNG gas into the combustion chamber with an injector suction. The CNG gas injection process is regulated by the programmable ECU through the VEMSTUNE software by adjusting start of injection (SOI) and duration injection (DI) of CNG gas. The result on SOI $45{ }^{\circ} \mathrm{CA}$ can substitution diesel fuel by $53.39 \%$ and the AFR value decreases by 22.29\%. Wisnu and Sudarmanta [5] conducted mapping start of injection and duration injection CNG through VEMSTUNE software, obtained results at $70{ }^{\circ} \mathrm{CA}$. Thermal efficiency value decreased by $58.5 \%$ and AFR value decreased by $70.63 \%$.

Papagiannakis et al [6] in his study conducted a natural gas-diesel fuel ratio gasoline arrangement using a supercharger and varying BMEP and engine speed. The results showed that every variation of speed and loading, high AFR (2.38, 2.04, 1.69) high BTE (0.2, 0.275, 0.325) than normal conditions (single fuel), decreasing CO emissions (16, 10, $7 \mathrm{~g} / \mathrm{KWh})$ and $\mathrm{HC}$ emissions (12, 7, 5 $\mathrm{g} / \mathrm{KWh}$ ), and increasing PM emissions (0.025, 0.07, 0.013 $\mathrm{mg} / \mathrm{l})$ but under normal diesel conditions. 
Based on the description above, it shows the tendency that the operation of a dual fuel system produces a richer mixture of fuel chambers. So thermal efficiency has decreased, while increasing the air fuel ratio through the addition of air supercharger can increase the amount of combustion air, improve engine performance and reduce emissions. In this research, we want to know the effect of the addition air mass flow rate of entering in combustion chamber by using electric supercharger on diesel engine type Diamond Di 800 which operated by dual fuel dieselCNG on engine performance and emission produced.

\section{METHOD}

This research was conducted with experimental method. The test is carried out on a diesel engine whose main shaft of the engine used as a test device is connected directly to the generator. Test method in this research is divided into two groups as follows: single fuel engine test with diesel fuel as the control group and dual fuel engine testing with diesel fuel and CNG fuel as the test group. Specification of diesel fuel and CNG are shown in the table 1 . The engine used is a diesel engine Diamond type Di 800 dual fuel system with a maximum power capability of $6 \mathrm{KW}$ with a continuous power of $5.02 \mathrm{KW}$. The complete engine specification in table 2. The loading used lamp is eight pieces with the power consumption of each 500-watt parallel arranged lamps equipped with switch for load setting. The CNG fuel used in this study pressurized 2 bars with a lower calorific value of $10799 \mathrm{Kcal} / \mathrm{kg}$. The CNG fuel feeding process with dual fuel system uses an electronically controlled indirect injection model using Vemstone Electronic Control Unit (ECU). CNG fuel is injected through an intake manifold adapted to the loading of a given lamp. While the air mass flow rate (m) is controlled by voltage on the electric supercharger using a voltage regulator. The test scheme of the duel fuel system as follows (Figure 1.):

The test procedure is carried out by varying the air mass flow rate (m) through intake manifold to the combustion chamber $0.0063 \mathrm{~kg} / \mathrm{s}, 0.0072 \mathrm{~kg} / \mathrm{s}, 0.0077 \mathrm{~kg} / \mathrm{s}, 0.0087$ $\mathrm{kg} / \mathrm{s}$, and $0.0095 \mathrm{~kg} / \mathrm{s}$ by adjusting voltage on the electric supercharger $8 \mathrm{~V}, 9 \mathrm{~V}, 10 \mathrm{~V}, 11 \mathrm{~V}$, and $12 \mathrm{~V}$. Each one variation of air mass flow rate (m) is carried out gradually from 1000 Watt to 4000 Watt and each stage of loading is done by taking data. Measurements of data taken include air mass flow rate, CNG mass flow rate, consumption time of diesel fuel every $25 \mathrm{ml}$, temperature (diesel engine, exhaust gas, lubricating oil, coolant), current, voltage and emission. Engine rotation during test is kept constant at 1500 rpm and a constant CNG pressure of 2 bart.

\section{RESULTS AND DISCUSSION}

Here are some parameters that indicate engine performance and emissions:

\section{A. Power (Ne)}

In Figure 2, it is generally shown that there is an increase effective power in line with the addition of electrical load. At the time of adding the electrical load will cause an increase power in the engine along with the addition of air and fuel to maintain the engine rotation remains constant at $1500 \mathrm{rpm}$. At the time of the addition a lot of fuel and the ideal air causes more energy is converted into hot enegi resulting from a large combustion and then converted into translational motion by the piston (mechanical).

\section{B. Torque}

In figure 3 , it is generally shown that there is a increasing torque with the addition of load. At the adding load greater, the incoming energy to overcome the load and maintain the rotation to remain constant so that the greater heat energy generated. The heat energy of the fuel converted into mechanical energy will increase, which is a representation of the thrust force on the piston. When the thrust force on the piston increase, then the torque will be increase. By adding the air mass flow rate $(\dot{\mathrm{m}})$ can produce a more perfect combustion so that the heat energy converted into mechanical energy will be greater.

\section{C. Втер}

The average effective pressure is the theoretical constant pressure that works along the piston volume step so to produce power equal to the effective power. In figure 4 , it shows that the increase power and torque is also followed by the increase BMEP as the load increases. This proves that the large amount of fuel energy and sufficient air, capable of producing higher pressure from combustion.

\section{Spesific Fuel Consumption (SFC)}

Based on Figure 6. SFC values for all tests decrease with increasing loading. In dual fuel condition, CNG consumption is kept constant in every loading. However, along with constant loads and CNG mass flow rate, diesel fuel consumption time will increase. But the load addition ratio is greater than the increase ratio of diesel consumption so that the SFC value decreases with the addition of load, on the same air mass flow rate.

\section{E. Diesel Fuel Substitution}

Diesel fuel substitution is the percentage amount of diesel oil replaced by CNG on each additional electrical load. Any addition of the air mass flow rate $(\dot{m})$ and the electrical load will affect the AFR at constant engine rpm. To obtain the ideal AFR value, then at each additional load required air mass flow rate $(\dot{m})$ greater, because the CNG mass flow rate $(\dot{m})$ constant. With the increase of the air mass flow rate, then the amount of percentage of diesel fuel injected into the combustion chamber to keep the constant engine rpm will be decrease, so that will get the ideal AFR value. In figure 7 , shows that in the variation more air mass flow rate $(\dot{m})$ can increase the percentage of the average diesel fuel by $56.45 \%$. 


\section{F. Air Fuel Ratio (AFR)}

Figure 8. shows that with the addition of air mass flow rate (m) using an electric supercharger can increase the average air-fuel ratio (AFR) by $64.31 \%$ compared to single fuel. In addition, the air mass flow rate of $0.0063 \mathrm{~kg} / \mathrm{s}$ is the lowest AFR condition in dual fuel. While the addition of air mass flow rate $(\dot{m})$ of $0.0095 \mathrm{~kg} / \mathrm{s}$ is the highest AFR condition, but at a low load of 1000 Watt the AFR value has exceeded the ideal limit because the mixture formed is a poorer mixture. Increasing the electrical load causes the AFR to decrease as the diesel fuel increases, while the air mass flow rate and CNG are always constant for each one of the variation conditions of the addition of air mass flow rate (m). Because increasing the load, the engine must produce a highest power. The greater power is generated from the burning of more fuel, and the added is diesel fuel.

\section{G. Thermal Efficiency}

Thermal efficiency is the value of the amount heat energy utilized stored in the fuel to be converted to effective power by internal combustion engine. From Figure 9. it can be seen that the highest thermal efficiency of the dual fuel system is at a variation in the air mass flow rate of 0.0087 $\mathrm{kg} / \mathrm{s}$ and then followed by a decrease in the value of thermal efficiency as the air mass flow rate decreases. The adding air mass flow rate is very important because it can support more complete combustion so that thermal efficiency becomes better. The average thermal efficiency of a dual-fuel system increased by $33.57 \%$ compared to single fuel.

\section{H. CO Emissions}

Figure 10. shows that $\mathrm{CO}$ emissions on dual fuel system engines are generally decrease although higher than single fuel. This is due to the mixed temperature of diesel fuel and CNG in the combustion chamber during the low expansion step, resulting in incomplete combustion and mixtures tend to be rich. At 4000 Watt load the highest $\mathrm{CO}$ emission is $0.006 \%$ in the air mass flow rate of $0.0063 \mathrm{~kg} / \mathrm{s}$, while the lowest CO is $0.0048 \%$ in the air mass flow rate of 0.0095 $\mathrm{kg} / \mathrm{s}$. With the addition of air mass flow rate and electrical load can be obtained the ideal AFR so it can reduce CO emissions although it remains above single fuel.

\section{HC Emissions}

Figure 11 shows that HC emissions on dual fuel system engines are generally decrease although higher than single fuel. This is due to the mixed temperature of diesel and CNG in the combustion chamber during the low expansion step, resulting in incomplete combustion and mixtures tend to be rich. At the load of 4000 Watt HC emission 15\% highest in air mass flow rate is $0.0063 \mathrm{~kg} / \mathrm{s}$, while the lowest HC emission $10 \%$ in air mass flow rate is 0.0095 $\mathrm{kg} / \mathrm{s}$. With the addition of air mass flow rate and electrical load can be obtained the ideal AFR so it can reduce HC emissions although if it remains above single fuel.

\section{J. Partikulat Matter (PM) Emissions}

Based on figure 12. above can be seen that with the operation of dual fuel system can reduce PM emissions by $75 \%$ compared to single fuel. This indicates that CNG fuel and with the addition of air mass flow rate are very effective at reducing PM emissions in diesel engines. However, with the addition of air mass flow rate and load, the emission of PM increases, but still below the single fuel condition.

TABLE 1.

FUEL SPECIFICATIONS

\begin{tabular}{lrc}
\hline \hline \multicolumn{1}{c}{ Fuel properties } & Diesel Fuel & CNG \\
\hline Low heating value $(\mathrm{MJ} / \mathrm{kg})$ & 42.8 & 48.6 \\
Cetane number & 52.5 & - \\
Octane number & & 130 \\
Auto-ignition temperature $\left({ }^{\circ} \mathrm{C}\right)$ & 316 & 650 \\
Stoichiometric air-fuel ratio $(\mathrm{kg} / \mathrm{kg})$ & 14.69 & 17.2 \\
Carbon content $(\%)$ & 87 & 75 \\
Density $(\mathrm{kg} / \mathrm{m} 3)$ & 860 & 0.56 \\
\hline \hline
\end{tabular}

TABLE 2.

ENGINE SPECIFICATIONS

\begin{tabular}{cc}
\hline \hline Name & Specification \\
\hline Merk & Diesel Diamond \\
Type & Di 800 \\
Model & 1 cylinder, 4 strokes \\
Bore x Stroke & $82 \mathrm{~mm} \mathrm{x} \mathrm{78} \mathrm{mm}$ \\
Displacement & $411 \mathrm{cc}$ \\
Max. Power & $8 \mathrm{HP}(6 \mathrm{KW}) / 2400 \mathrm{rpm}$ \\
Continous Power & $7 \mathrm{HP}(5.22 \mathrm{KW}) / 2200 \mathrm{rpm}$ \\
Compression Ratio & $18: 01$ \\
Cooling system & water cooling \\
Lube capacity & 1,8 liter \\
Injection pilot diesel & $13^{0} \mathrm{BTDC}$ \\
\hline \hline
\end{tabular}

\section{CONCLUSIONS}

The conclusions of this study are:

1) The addition of air mass flow rate (m) has no significant effect on power, torque, and Bmep when compared to single fuel.

2) The addition of air mass flow rate (m) of $0.0087 \mathrm{~kg} / \mathrm{s}$ can increase the average AFR by $64.31 \%$, increase thermal efficiency by $33.57 \%$, and fuel diesel substitution an average of $56.45 \%$.

In dual fuel diesel engines can reduce $\mathrm{CO}$ emissions average by $15.18 \%$ and $62.35 \%$ HC emissions although still above single fuel condition, while the PM emissions decreased on average by $75 \%$ under single fuel condition. 


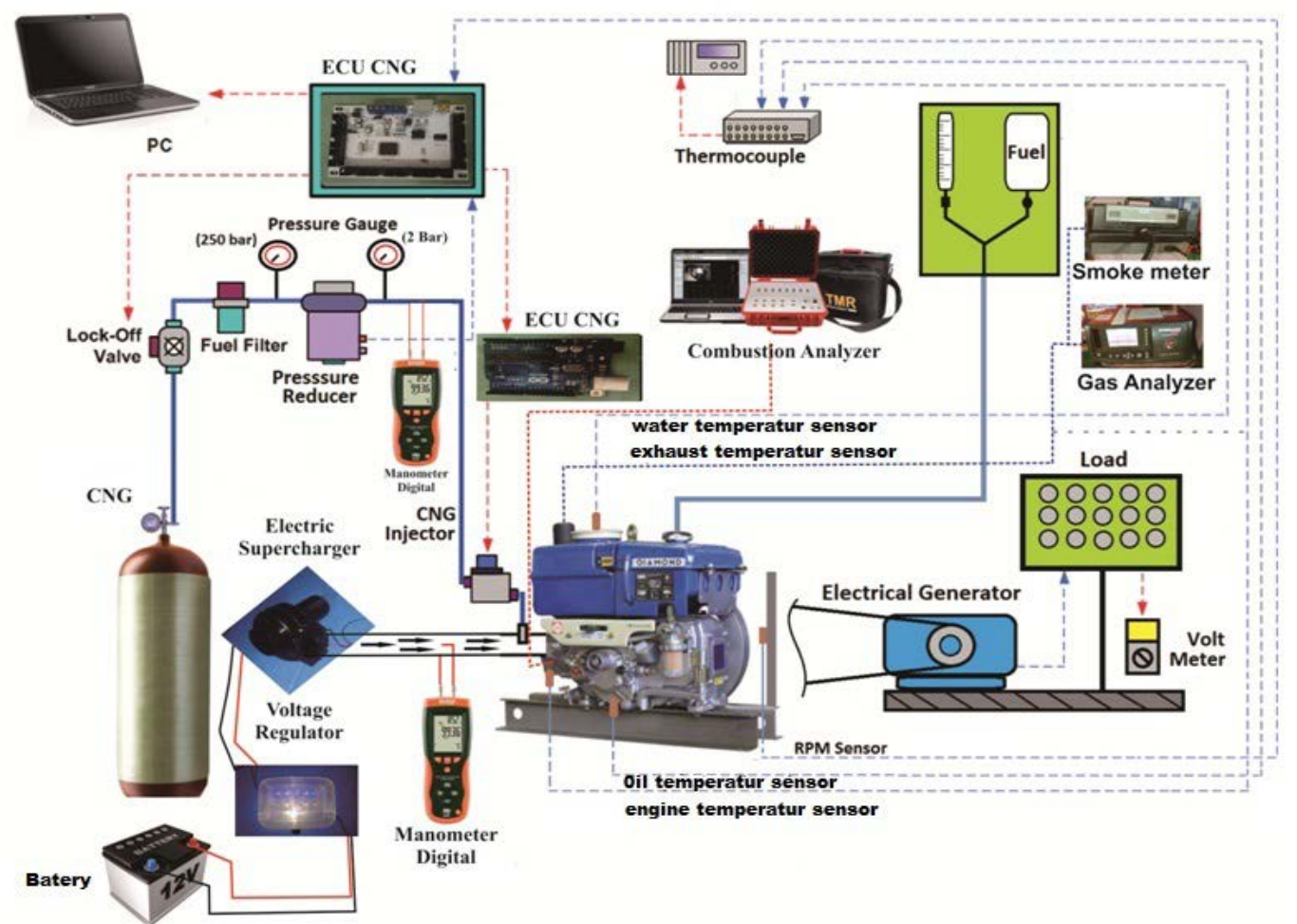

Figure 1. Schematic of Testing Design

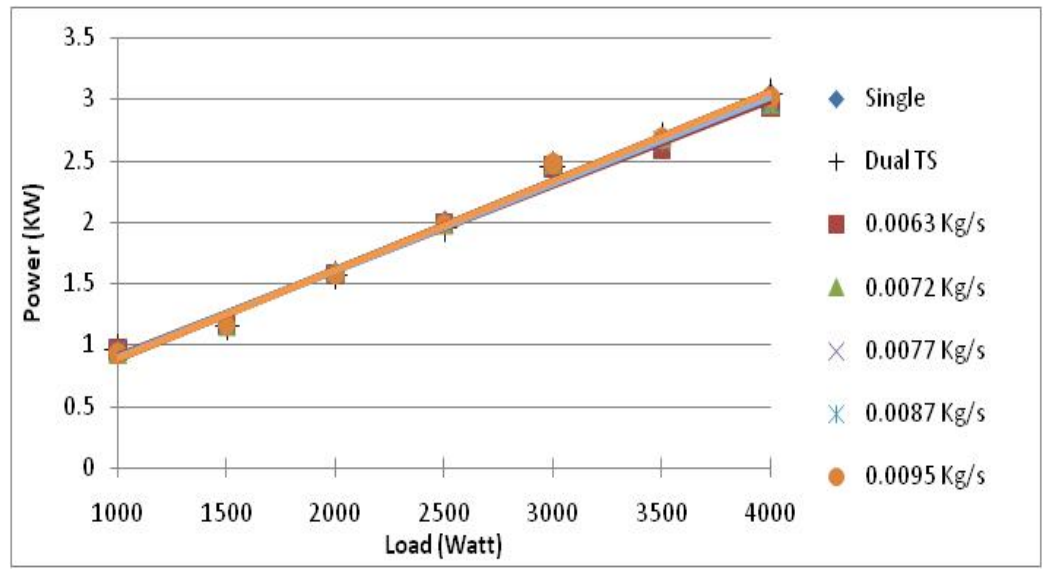

Figure 2. Chart Power Function Loads.

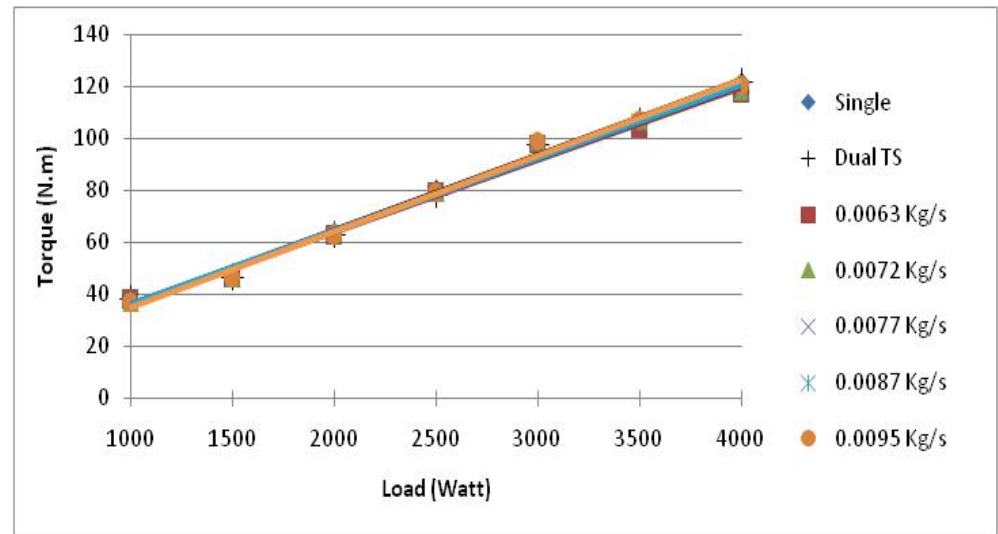

Figure 3. Chart Torque Function Loads. 


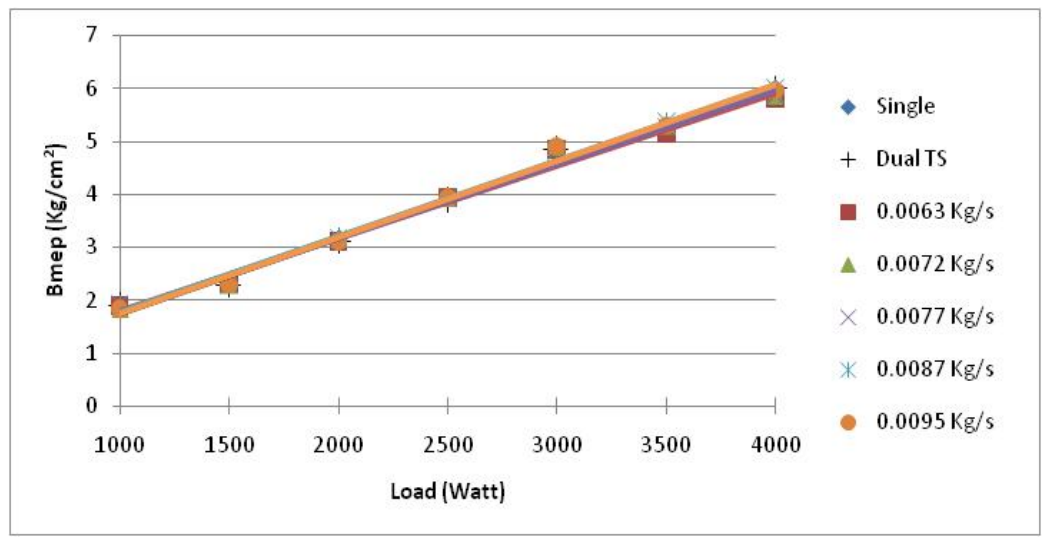

Figure 4. Chart Bmep Function Loads.

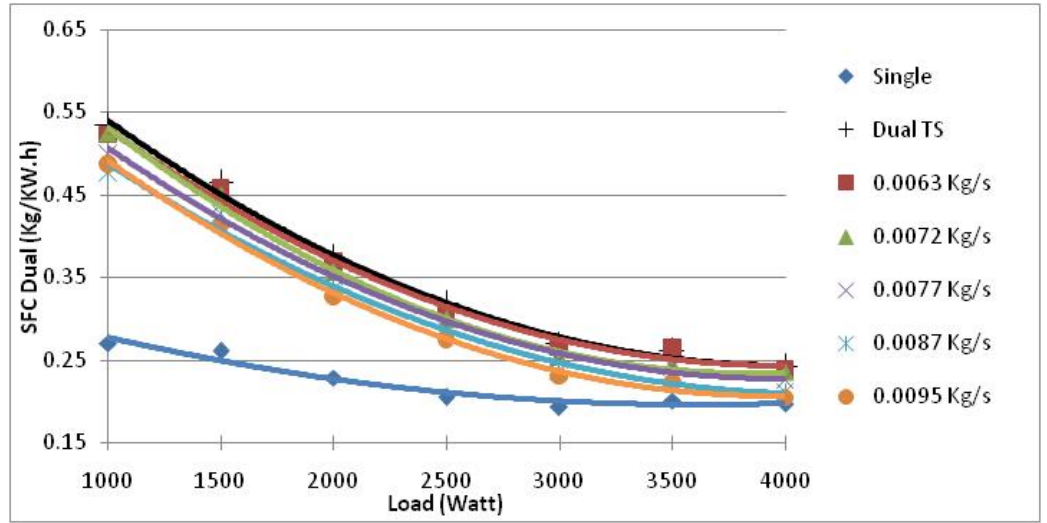

Figure 5. Chart SFC Function Loads.

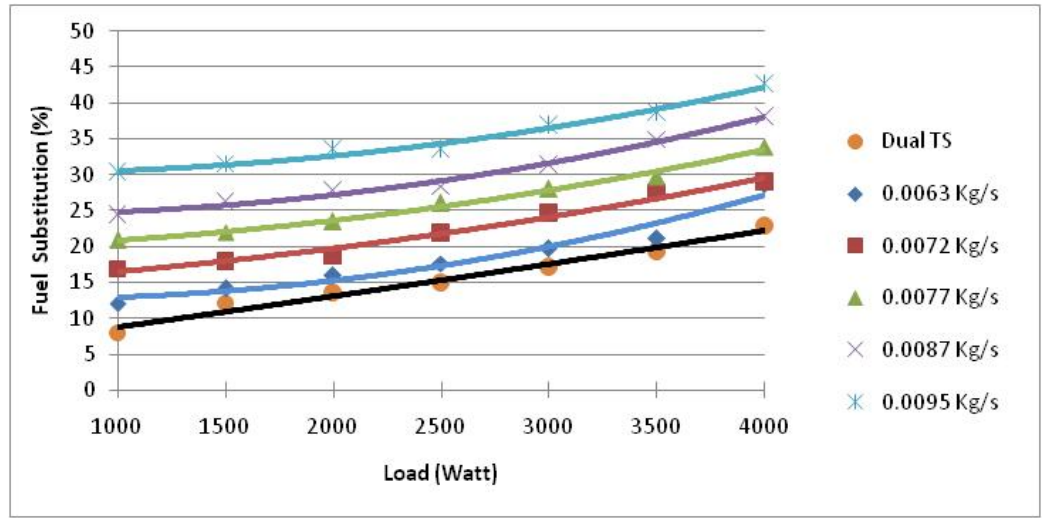

Figure 6. Chart Fuel Substitution Function Loads

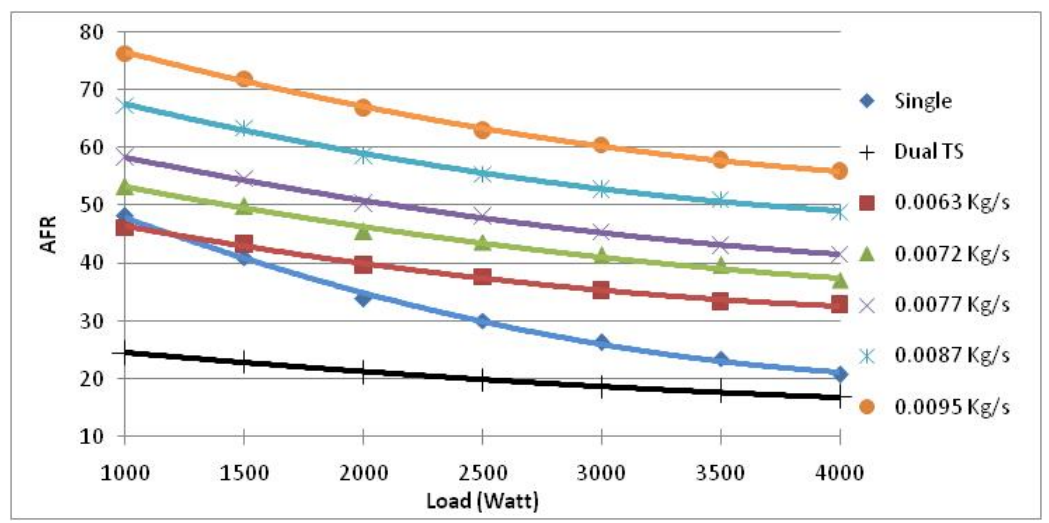

Figure 7. Chart AFR Function Loads. 


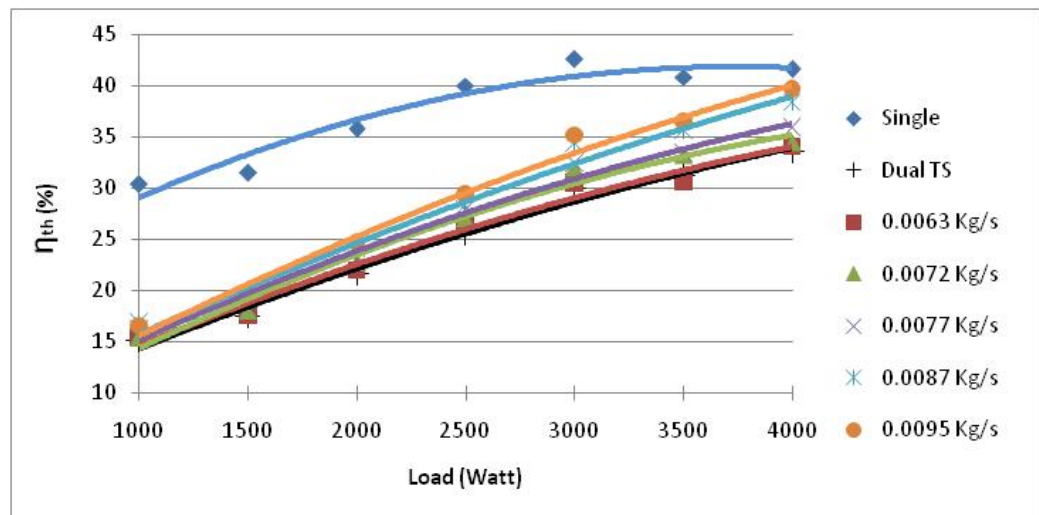

Figure 8. Chart Thermal Efficiency Function Loads.

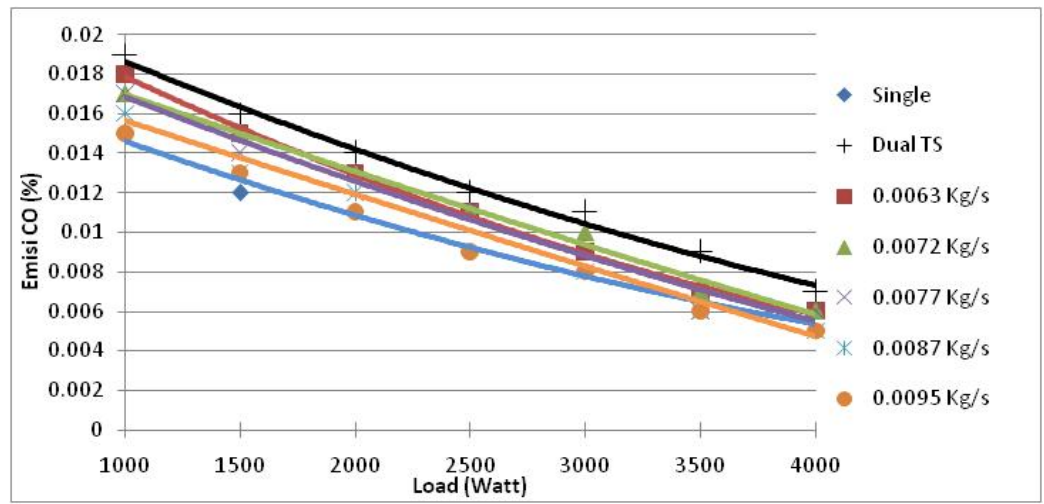

Figure 9. Chart CO Emissions Function Loads.

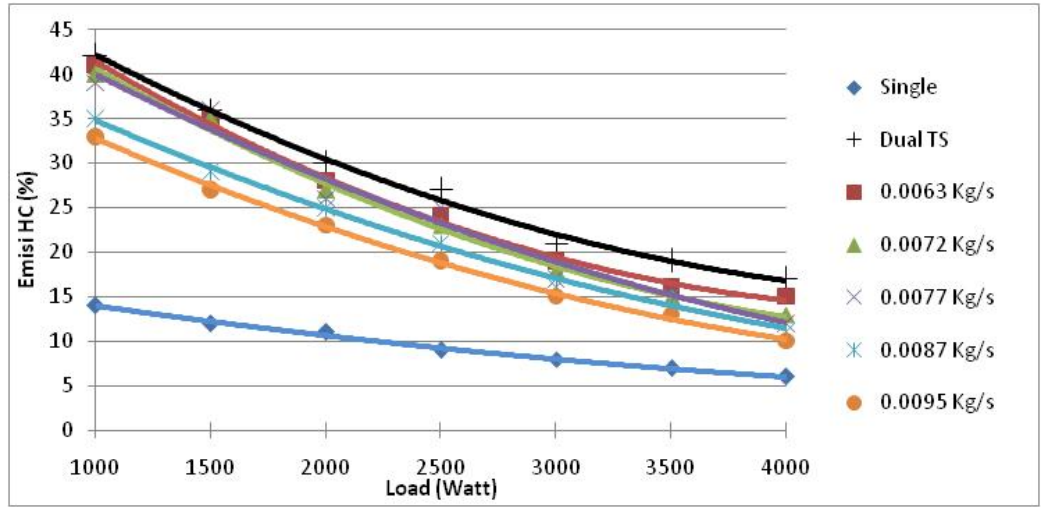

Figure 10. Chart HC Emissions Function Loads.

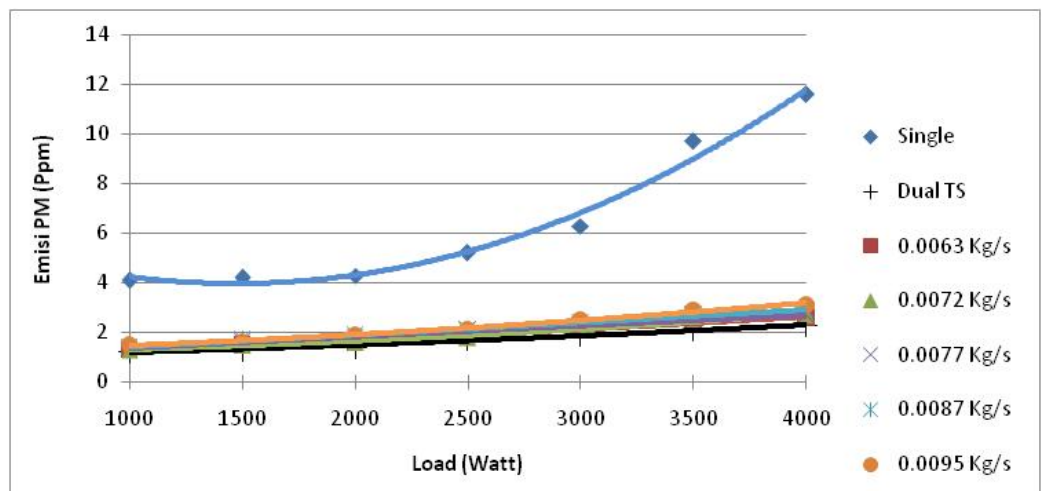

Figure 11. Chart PM Emissions Function Loads. 


\section{REFERENCES}

[1] F. Konigsson, "On Combustion in the CNG-Diesel Dual Fuel Engine,” Royal Institute of Technology, 2014.

[2] J. B. Heywood, Internal Combustion Engine Fundamentals, Internat. ed. New York: McGraw-Hill, 1988.

[3] D. Yuvenda and B. Sudarmanta, "Karakterisasi performa mesin sistem dual fuel menggunakan pressure reducer adaptive dengan variasi konstanta $(\mathrm{k})$ pegas helix tekan dan tekanan gas keluar pada stage dua," in Prosiding Seminar Nasional Manajemen Teknologi XXIII, 2015, p. 24.2-24.8.
[4] A. Arif and B. Sudarmanta, "Karakterisasi performa mesin diesel dual fuel solar-CNG tipe LPIG dengan pengaturan start of injection dan durasi injeksi," in Prosiding Seminar Nasional Manajemen Teknologi XXIII, 2015, p. 1.1-1.8.

[5] Z. Wisnu and B. Sudarmanta, "Studi Eksperimen Pengaruh Variasi Start Of Injection Dan Durasi Pemasukan Bahan Bakar Compressed Natural Gas Terhadap Performa Mesin Diesel Sistem Dual Fuel," Institut Teknologi Sepuluh Nopember, 2015.

[6] R. G. Papagiannakis, C. D. Rakopoulos, D. T. Hountalas, and D. C. Rakopoulos, "Emission characteristics of high speed, dual fuel, compression ignition engine operating in a wide range of natural gas/diesel fuel proportions," Fuel, vol. 89, no. 7, pp. 1397-1406, Jul. 2010. 